\title{
Anteseden Dari Psychological Empowerment Dan Dampaknya Terhdap Nurses Burnout (Studi Empiris Pada Rumah Sakit XYZ Di Tangerang Saat Pandemi COVID-19)
}

\author{
Jason, Ferdi Antonio \\ Graduate School of Management, Universitas Pelita Harapan, Jakarta, Indonesia \\ jasonbustam@gmail.com
}

\begin{abstract}
Abstrak
Tujuan penelitian ini adalah untuk menguji pengaruh anteseden dari psychological empowerment terhadap burnout pada perawat yang bekerja di Rumah Sakit XYZ di Tangerang saat pandemi. PLS-SEM digunakan untuk menganalisis data empiris yang diperoleh melalui simple random sampling. Didapatkan 80 responden yang memenuhi syarat melalui kuesioner yang telah didistribusikan secara online. Hasil penelitian menunjukkan bahwa enam dari delapan variabel kualitas kehidupan kerja, serta variabel mediasi psychological empowerment mempunyai pengaruh yang negatif yang signifikan pada burnout. Pengaruh langsung pada psychological empowerment ditemukan paling kuat dari opportunity to develop human capital dan adequate and fair compensation. Ditemukan dampak negatif dari psychological empowerment terhadap burnout, dengan demikian hasil penelitian ini mendukung teori kualitas kehidupan kerja dapat meningkatkan pemberdayaan psikologis di antara perawat, sekaligus menunjukkan aplikasi yang baru terhadap pemberdayaan psikologis perawat. Model penelitian ini memiliki moderate predictive accuracy dan medium predictive relevance, sehingga dapat dikembangkan dalam penelitian lebih lanjut. Terdapat implikasi manajerial yang didapatkan dari temuan penelitian ini serta rekomendasi bagi peneliti selanjutnya.
\end{abstract}

Kata kunci: Pandemi COVID-19, kualitas kehidupan kerja, pemberdayaan psikologis, burnout, perawat.

Abstract

The purpose of this study was to examine the effect of the antecedents of psychological empowerment on burnout in nurses working at the COVID-19 Hospital XYZ in Tangerang during the pandemic. PLS-SEM was used to analyze empirical data obtained through simple random sampling. There were 80 respondents who met the requirements through questionnaire that had been distributed online. The results showed that six of the eight variables of quality of work life, as well as psychological empowerment mediating variables, had a significant negative effect on burnout. The direct influence on psychological empowement was found to be the strongest from the opportunity to develop human capital and adequate and fair compensation. It was found that there was a negative impact of psychological empowerment on burnout, thus the results of this study support the theory that the quality of work life can increase psychological empowerment among nurses, as well as show a new application to the psychological empowerment of nurses. This research model has moderate predictive accuracy and medium predictive relevance, so it can be developed in further research. There are managerial implications obtained from the findings of this study as well as recommendations for future researchers.

Keywords: COVID-19 pandemic, quality of work life, psychological empowerment, burnout, nurse.

\section{PENDAHULUAN}

Pada Desember 2019, infeksi yang tidak diketahui penyebabnya dimulai di Wuhan, China menimbulkan perhatian yang luar biasa (Catton, 2020). Para ahli WHO menegaskan bahwa patogen penyebab pneumonia baru ini adalah SARSCoV-2, dan disebut Penyakit Coronavirus 2019 atau COVID-19 (Pan et al., 2020). Rute transmisi utama dari virus ini adalah melalui droplet yang berasal dari pernapasan dan kontak erat, yang membuat perawat dan dokter menjadi populasi yang berisiko tinggi. Berdasarkan laporan dari tim ahli WHO-China, pada Februari 2020 sudah didapatkan 2055 tenaga kesehatan yang terdiri dari 476 rumah sakit berbeda, menderita Covid-19 (Liu et al., 2020). Jumlah pasien terus meningkat seiring berjalan waktu, hal ini membuat para perawat dan dokter harus menghadapi beban kerja yang luar biasa dan 
risiko tinggi terhadap paparan infeksi, yang berujung pada masalah kesehatan mental seperti ansietas dan depresi (Kang et al.,

2020). Penelitian menyebutkan bahwa upaya menjaga kesehatan mental para dokter dan perawat dapat berkontribusi positif dalam mengendalikan penyakit (Chen et al., 2020). Perawat merupakan profesi yang mulia dan memainkan peran penting untuk pelayanan dan perawatan kesehatan di negara mana pun. Perawat bekerja dengan pasien dan dokter dalam melayani pasien. Peran perawat sangatlah penting, dan tugas mereka dapat dikatakan tidak terhitung banyaknya (Khamisa, Peltzer, Oldenburg, 2013). Sifat pekerjaan yang dialami perawat menjadikannya salah satu profesi yang paling memberikan tekanan. Perawat diharuskan untuk memiliki ketahanan fisik dan emosional yang tinggi untuk menangani masalah terkait pekerjaan sehingga mereka dapat bekerja lebih baik lagi (Schaufeli, 2006).

Rumah sakit saat ini mengandalkan perawat dalam kualitas pelayanan karena industri rumah sakit mengalami persaingan yang ketat. Kualitas pelayanan rumah sakit merupakan isu penting dalam meningkatkan kepuasan pasien. Perawat sebagai pemberi pelayanan kesehatan yang dalam menjalankan tugas secara terus menerus mengadakan kontak baik dengan pasien, kolega, atasan atau dengan anggota tim kesehatan lain. Pasien yang puas dengan pelayanan yang diberikan merupakan aset yang berharga. Oleh sebab itu diperlukan tenaga kesehatan yang prima yang mampu memberikan pelayanan yang maksimal. Dalam kondisi kompetitif seperti ini, manajemen rumah sakit harus fokus dalam mencapai hal yang lebih baik dari rumah sakit lainnya. Oleh sebab itu, manajemen rumah sakit perlu memperhatikan kualitas tenaga kerja yang dimilikinya dan bukan hanya dari segi fisik saja melainkan juga dari aspek psikologis agar tercipta pelayanan yang lebih baik bagi pasien.

Rumah Sakit XYZ merupakan rumah sakit swasta yang berlokasi di Tangerang, Provinsi Banten, Indonesia. RS XYZ merupakan rumah sakit tipe C dan berfungsi memberikan pelayanan untuk pasien COVID-19. Dengan luas lahan sekitar 10.250 meter persegi, RS XYZ memiliki kapasitas pasien sekitar 248 tempat tidur dan terus berkembang. Tipe kamar yang disediakan oleh RS XYZ diantaranya adalah ruang perawatan intensif, ruang perawatan kelas 1, 2 dan 3 . Fasilitas yang disediakan oleh RS XYZ adalah ambulans, layanan diagnostik, radiologi dan laboratorium. Pada saat pandemi COVID-19, RS XYZ hanya menerima layanan rawat inap untuk pasien terinfeksi COVID-19 dan menutup layanan poliklinik untuk sementara. RS XYZ menyediakan layanan pemeriksaan COVID-19 seperti swab antigen dan pemeriksaan polymerase chain reaction (PCR). Alasan pemilihan RS XYZ menjadi target penelitian ini adalah karena merupakan RS swasta pertama di Tangerang yang mendedikasikan diri untuk menjadi rujukan COVID-19 pertama dan menerima rujukan bukan dari jejaringnya saja melainkan dari seluruh rumah sakit atau fasilitas kesehatan lainnya.

Saat ini, studi tentang situasi epidemi COVID-19 lebih banyak difokuskan pada investigasi epidemiologi, pencegahan dan pengendalian, diagnosis dan pengobatan. Lebih sedikit penelitian yang menyelidiki masalah kesehatan mental pekerja medis klinis selama epidemi COVID-19. Kesehatan dan kesejahteraan perawat menjadi menurun akibat beberapa faktor seperti praktik keperawatan yang rumit, tuntutan pasien, beban kerja, dan kondisi tempat kerja, yang semuanya menghasilkan frustasi dan berujung pada burnout, terutama kelelahan secara emosional (Demerouti, Bakker, Nachreiner, Schaufeli, 2000). Penelitian ini bertujuan untuk mengetahui pengaruh kualitas kehidupan kerja terhadap psychological empowerment tenaga keperawatan di RS XYZ pada tahun 2021 dan bagaimana psychological empowerment dapat mempengaruhi burnout. Perbaikan untuk kondisi ini di kemudian hari bergantung pada manajemen institusi perawatan kesehatan atau rumah sakit dalam menentukan penyebab dari burnout dan menyediakan kondisi kerja yang diperlukan untuk mengurangi risiko burnout pada perawat kedepannya.

\section{METODOLOGI PENELITIAN}

Tipe penelitian ini merupakan studi cross-sectional, kuantitatif dengan uji hipotesis, correlational, dan bukan bersifat kausalitas (sebab-akibat) antar variabel dalam penelitian. Penelitian ini juga merupakan non-interventional yang berarti tidak ada perlakuan khusus atau intervensi yang dilakukan terhadap subjek penelitian. Penelitian difokuskan pada RS XYZ di Tangerang, Provinsi Banten yang merupakan rumah sakit tipe $C$ dan semenjak pandemi berfungsi 
memberikan pelayanan untuk pasien COVID-19. Berdasarkan teori quality of work life diketahui bahwa kompensasi, konstitusi, peluang, kondisi tempat kerja, jangka waktu kerja dan integrasi serta relevansi sosial dari tempat kerja memegang peranan penting. Komponen quality of work life tersebut berpengaruh pada pemberdayaan psikologis karyawan (Salimi \& Saeidian, 2015).

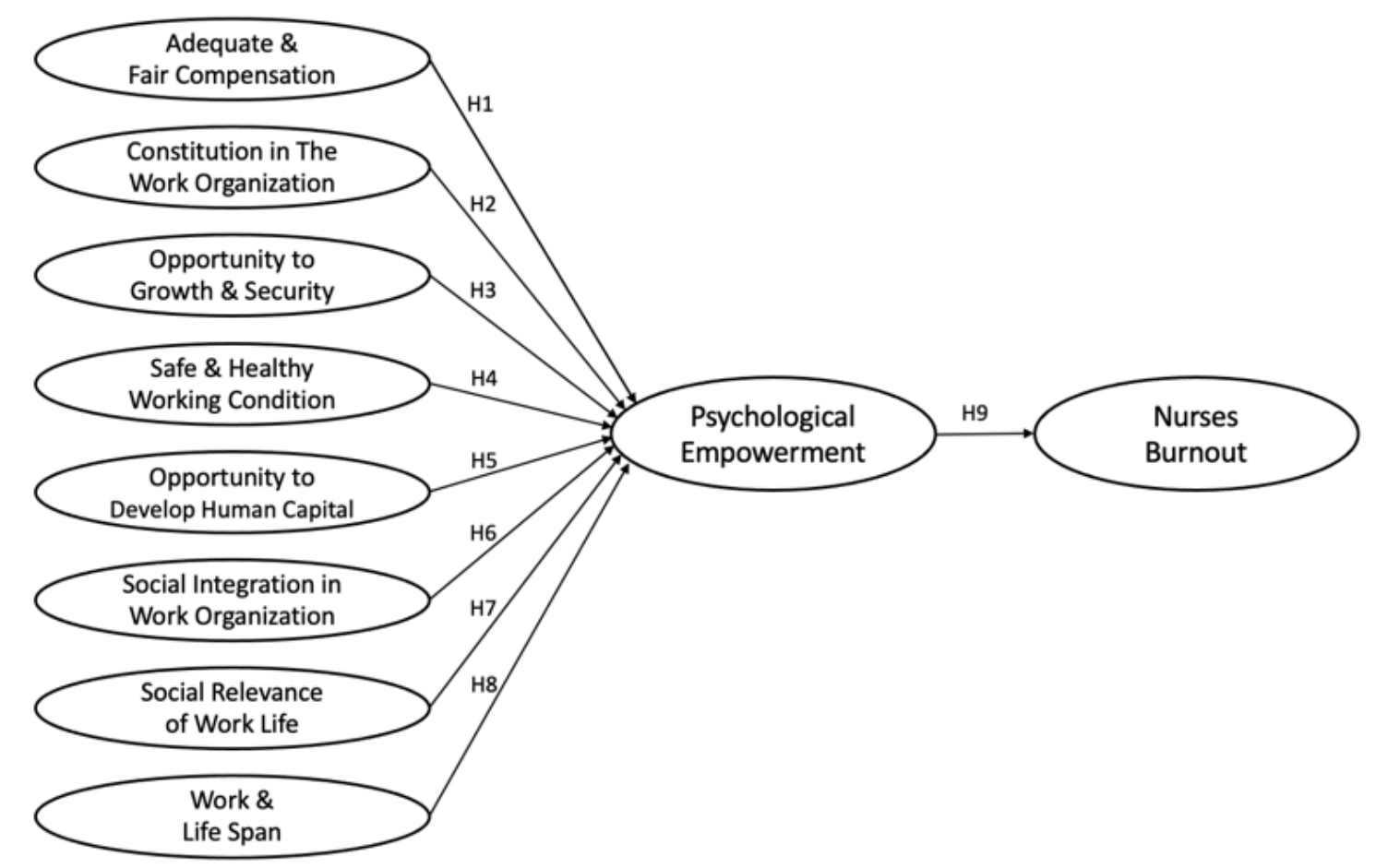

Gambar 1. Model Penelitian

Sumber: Permarupan et al. (2020)

Pada model penelitian ini variabel psychological empowerment diuji dampaknya pada burnout sebagai variabel dependen penelitian. Penelitian menggunakan model penelitian yang pernah dilakukan oleh peneliti terdahulu (Permarupan et al., 2020), diuji secara empiris pada perawat yang melakukan pelayanan pada pasien terduga ataupun terkonfirmasi COVID-19 di RS XYZ di Tangerang. Objek dalam penelitian ini adalah semua variabel yang termasuk dalam model penelitian ini. Variabel terikat penelitian ini adalah burnout, sedangkan psychological empowerment sebagai variabel mediasi. Unit analisis merupakan unit analisis individual yang berarti data diperoleh berasal dari individu yang diambil berdasarkan masing-masing responden. Dua kriteria wajib responden yang harus dipenuhi: pertama, responden adalah perawat tetap atau full timer, kedua, responden melakukan perawatan atau pelayanan pada pasien COVID-19. Alasan dalam memilih perawat sebagai unit analisis adalah karena perawat memiliki waktu bersinggungan dengan pasien COVID-19 lebih banyak dibandingkan dengan tenaga kesehatan lainnya dan karena belum banyaknya penelitian yang menggunakan jenis responden tersebut saat periode pandemi COVID-19 sedang berlangsung. Penelitian ini menggunakan skala ordinal untuk menentukan perbedaan tiap konstruk dan memudahkan konversi data yang diterima dari responden dari item-item kuesioner kedalam bentuk numerik atau angka, dengan menggunakan skala Likert. 
Tabel 1. Definisi Konseptual dan Operasionalisasi Variabel

\begin{tabular}{|c|c|c|c|}
\hline Variabel & Definisi Konseptual & $\begin{array}{c}\text { Operasionalisasi } \\
\text { Variabel }\end{array}$ & $\begin{array}{c}\text { Sumber / } \\
\text { Skala }\end{array}$ \\
\hline $\begin{array}{l}\text { Adequate and Fair } \\
\text { Compensation } \\
\text { (AFC) }\end{array}$ & $\begin{array}{l}\text { Gaji yang memenuhi } \\
\text { standar secara umum dan } \\
\text { cukup untuk memenuhi } \\
\text { tingkat hidup yang layak, } \\
\text { dan mempunyai per- } \\
\text { bandingan yang sama } \\
\text { dengan gaji yang diperoleh } \\
\text { orang lain di posisi yang } \\
\text { serupa (Kanten dan Sadul- } \\
\text { lah, 2012). }\end{array}$ & $\begin{array}{l}\text { 1. Saya merasa gaji (remunerasi) yang saya } \\
\text { dapatkan adalah wajar. } \\
\text { 2. Saya merasa puas dengan gaji saya } \\
\text { dibandingkan dengan gaji kolega saya. } \\
\text { 3. Saya merasa hadiah/penghargaan yang } \\
\text { saya dapatkan (contoh: insentif COVID) dari } \\
\text { RS tempat saya bekerja sudah berjalan baik. } \\
\text { 4. Saya merasa manfaat tambahan (contoh: } \\
\text { edukasi, kursus, CME) dari RS tempat saya } \\
\text { bekerja sudah baik. }\end{array}$ & $\begin{array}{l}\text { Walton } \\
(1975) \\
\text { Skala Likert } \\
\text { (1 sd 5) }\end{array}$ \\
\hline $\begin{array}{l}\text { Constitutionalism } \\
\text { in Work (CW) }\end{array}$ & $\begin{array}{l}\text { Hak-hak yang dimiliki oleh } \\
\text { karyawan dan bagaimana } \\
\text { hal tersebut dapat } \\
\text { digunakan untuk } \\
\text { melindungi karyawan } \\
\text { (Kanten dan Sadullah, } \\
\text { 2012). }\end{array}$ & $\begin{array}{l}\text { 1. Saya merasa usaha RS tempat saya } \\
\text { bekerja dalam menghormati hak-hak } \\
\text { pekerja sudah layak. } \\
\text { 2. Saya merasa kebebasan untuk berekspresi } \\
\text { (kesempatan untuk mengungkapkan pen- } \\
\text { dapat) yang ada di RS tempat saya bekerja } \\
\text { berjalan baik. } \\
\text { 3. Saya merasa norma dan aturan yang ber- } \\
\text { laku di RS tempat saya bekerja adalah wajar. } \\
\text { 4. Saya merasa perlakuan oleh RS tempat } \\
\text { saya bekerja terhadap karakteristik dan } \\
\text { kekhasan setiap individu pekerja sudah } \\
\text { layak. }\end{array}$ & $\begin{array}{l}\text { Walton } \\
\text { (1975) } \\
\text { Skala Likert } \\
\text { (1 sd 5) }\end{array}$ \\
\hline $\begin{array}{l}\text { Opportunity to } \\
\text { grow and security } \\
\text { at work (OW) }\end{array}$ & $\begin{array}{l}\text { Ketersediaan peluang un- } \\
\text { tuk bisa maju dalam or- } \\
\text { ganisasi atau karir, dan } \\
\text { keamanan status atau } \\
\text { pendapatan yang berhub- } \\
\text { ungan dengan pekerjaan } \\
\text { (Walton, 1975). }\end{array}$ & $\begin{array}{l}\text { 1. Saya merasa peluang untuk berkembang } \\
\text { di rumah sakit saat ini baik. } \\
\text { 2. Saya merasa pelatihan-pelatihan yang } \\
\text { diberikan oleh RS tempat saya bekerja ber- } \\
\text { langsung dengan baik. } \\
\text { 3. Saya merasa pekerja yang mengajukan } \\
\text { pengunduran diri di RS tempat saya bekerja } \\
\text { adalah wajar. } \\
\text { 4. Saya merasa dukungan atau kesempatan } \\
\text { yang diberikan rumah sakit untuk } \\
\text { studi/melanjutkan pendidikan berjalan baik. }\end{array}$ & $\begin{array}{l}\text { Walton } \\
(1975) \\
\text { Skala Likert } \\
(1 \text { sd } 5)\end{array}$ \\
\hline $\begin{array}{l}\text { Safe and Healthy } \\
\text { Working Condi- } \\
\text { tions (WC) }\end{array}$ & $\begin{array}{l}\text { Lingkungan yang aman dan } \\
\text { sehat untuk karyawan } \\
\text { yang berkaitan dengan } \\
\text { kenyamanan dalam hal } \\
\text { fisik dan kesehatan (Kan- } \\
\text { ten dan Sadullah, 2012). }\end{array}$ & $\begin{array}{l}\text { 1. Saya merasa jam kerja mingguan (jumlah } \\
\text { jam kerja/shift) pekerjaan saya adalah wajar. } \\
\text { 2. Saya merasa beban kerja saya saat ini } \\
\text { adalah wajar. } \\
\text { 3. Saya merasa penggunaan teknologi dalam } \\
\text { pekerjaan saya berlangsung dengan baik. } \\
\text { 4. Saya merasa kesehatan di RS tempat kerja } \\
\text { saya (contoh: kebersihan) sudah layak. } \\
\text { 5. Saya merasa peralatan keselamatan, APD, } \\
\text { dan perlindungan yang diberikan oleh ru- } \\
\text { mah sakit sudah layak. } \\
\text { 6. Saya merasa kelelahan yang disebabkan } \\
\text { oleh pekerjaan saya adalah wajar. }\end{array}$ & $\begin{array}{l}\text { Walton } \\
(1975) \\
\text { Skala Likert } \\
(1 \text { sd } 5)\end{array}$ \\
\hline $\begin{array}{l}\text { Opportunity to De- } \\
\text { velop Human Capi- } \\
\text { tal (UCW) }\end{array}$ & $\begin{array}{l}\text { Pengembangan kapasitas } \\
\text { manusia yang menunjuk- } \\
\text { kan adanya penyediaan } \\
\text { lingkungan kerja yang }\end{array}$ & $\begin{array}{l}\text { 1. Saya merasa otonomi (kesempatan untuk } \\
\text { membuat keputusan) yang saya miliki di ru- } \\
\text { mah sakit sudah wajar. }\end{array}$ & $\begin{array}{l}\text { Walton } \\
\text { (1975) } \\
\text { Skala Likert }\end{array}$ \\
\hline
\end{tabular}


memfasilitasi pekerjanya untuk mendapat kesempatan dan memperoleh otonomi (Kanten dan Sadullah, 2012).

\section{Social Integration at Work (SIW)}

\section{Social Relevance and Importance of Work (SRI)}

\section{Work and Life Span (OSW)}

\section{Psychological Em-} powerment (PE)
Komponen penting yang

berkaitan dengan

bagimana karyawan memiliki perasaan kepemilikan terhadap perusahaan (Kanten dan Sadullah, 2012).

Sikap tanggung jawab yang diberikan oleh perusahaan dalam menjaga kualitas kondisi kerja secara sosial (Kanten dan Sadullah, 2012).

Keseimbangan dari peran kerja seseorang dengan kehidupannya (Walton, 1975).

Persepsi terhadap kontrol karyawan atas lingkungan kerja mereka dan keselarasan antara nilai dan keyakinan terkait pekerjaan mereka, dan pemberi kerja mereka (Spreitzer, 1995).
2. Saya merasa tugas / pekerjaan / aktivitas yang saya lakukan adalah hal yang penting. 3. Saya merasa melakukan beberapa tugas pada waktu yang bersamaan adalah hal yang wajar.

4. Saya merasa sistem penilaian kinerja yang ada di rumah sakit berjalan baik.

5. Saya merasa tanggung jawab yang diberikan kepada saya adalah wajar.

1. Saya merasa perlakuan terhadap sosial, rasial, agama, jenis kelamin, dan lainnya yang ada di RS tempat saya bekerja sudah selayaknya.

2. Saya merasa relasi saya dengan rekan kerja dan atasan berlangsung dengan baik.

3. Saya merasa komitmen yang sudah dibuat oleh tim dan rekan kerja saya sudah berjalan dengan baik.

4. Saya merasa penerimaan atau apresiasi yang diberikan kepada saya saat menyampaikan ide-ide dan inisiatif sudah layak.

1. Saya merasa bangga dengan pekerjaan yang saya lakukan.

2. Saya merasa citra rumah sakit yang ada di masyarakat sudah baik.

(1 sd 5)

Walton

Skala Likert

(1 sd 5)

3. Saya merasa kontribusi rumah sakit tempat saya bekerja kepada masyarakat sudah baik.

4. Saya merasa pelayanan yang diberikan oleh RS tempat saya bekerja sudah sewajarnya.

5. Saya merasa cara karyawan diperlakukan di RS tempat saya bekerja sudah layak.

1. Saya merasa pengaruh pekerjaan saya terhadap keluarga dan rutinitas saya sudah sewajarnya.

2. Saya merasa pengaruh pekerjaan saya ter- Skala Likert hadap waktu senggang saya sudah sewajarnya.

3. Saya merasa pembagian jadwal kerja dan waktu istirahat saya sudah baik.

1. Pekerjaan yang saya lakukan penting bagi saya.

2. Aktivitas pekerjaan saya berarti bagi saya secara pribadi.

Walton

Skala Likert

(1 sd 5)

Walton

(1975)

(1 sd 5)

Spreitzer

(1995)

3. Pekerjaan yang saya lakukan bernilai bagi saya.

4. Saya yakin bahwa saya mempunyai kemampuan untuk mengerjakan pekerjaan saya.

5. Saya merasa percaya diri akan kapabilitas saya untuk melakukan aktivitas pekerjaan saya.

6. Saya telah menguasai keterampilan yang diperlukan untuk pekerjaan saya.
Skala Likert

(1 sd 5) 


\begin{tabular}{|c|c|c|c|}
\hline & & $\begin{array}{l}\text { 7. Saya memiliki otonomi dalam menen- } \\
\text { tukan bagaimana saya melakukan pekerjaan } \\
\text { saya. } \\
\text { 8. Saya dapat memutuskan sendiri } \\
\text { bagaimana cara mengerjakan hal terkait } \\
\text { pekerjaan saya. } \\
\text { 9. Saya memiliki cukup banyak kesempatan } \\
\text { untuk melakukan aktivitas terkait pekerjaan } \\
\text { saya secara bebas. } \\
\text { 10. Saya memiliki dampak yang besar ter- } \\
\text { hadap RS tempat saya bekerja. } \\
\text { 11. Saya memiliki banyak kendali/kontrol } \\
\text { atas apa yang terjadi di RS tempat saya } \\
\text { bekerja. } \\
\text { 12. Saya memiliki pengaruh yang signifikan } \\
\text { atas apa yang terjadi di RS tempat saya } \\
\text { bekerja. }\end{array}$ & \\
\hline Burnout (NB) & $\begin{array}{l}\text { Sindrom kelelahan emo- } \\
\text { sional yang sering terjadi } \\
\text { di antara individu yang } \\
\text { ditandai dengan pening- } \\
\text { katan perasaan kelelahan } \\
\text { secara emosional (Maslach } \\
\text { \& Jackson, 1981). }\end{array}$ & $\begin{array}{l}\text { 1. Saya merasa terkuras secara emosional } \\
\text { akibat pekerjaan saya. } \\
\text { 2. Saya merasa lelah di akhir shift saya. } \\
\text { 3. Saya merasa lelah ketika bangun di pagi } \\
\text { hari dan harus menghadapi pekerjaan yg } \\
\text { sama } \\
\text { 4. Bekerja dengan orang-orang di RS ini } \\
\text { sepanjang hari membebani saya. } \\
\text { 5. Saya sering merasa frustasi dengan peker- } \\
\text { jaan saya. } \\
\text { 6. Saya sulit memahami bagaimana } \\
\text { perasaan pasien saya. } \\
\text { 7. Saya merasa saya menangani masalah } \\
\text { pasien dengan tidak efektif. } \\
\text { 8. Saya merasa tidak berenergi ketika se- } \\
\text { dang bertugas. } \\
\text { 9. Saya merasa murung setelah bekerja } \\
\text { sama dengan pasien. } \\
\text { 10. Saya merasa saya memperlakukan } \\
\text { pasien saya seolah-olah mereka hanya se- } \\
\text { bagai 'objek'. } \\
\text { 11. Saya menjadi lebih tidak sensitif ter- } \\
\text { hadap orang sejak saya bekerja pada masa } \\
\text { pandemi COVID-19. } \\
\text { 12. Saya merasa tidak terlalu peduli dengan } \\
\text { perasaan pasien. } \\
\text { 13. Saya merasa pasien sering menyalahkan } \\
\text { saya atas keluhan mereka. }\end{array}$ & $\begin{array}{l}\text { Maslach } \\
\text { (1981) } \\
\text { Skala Likert } \\
\text { (1 sd 5) }\end{array}$ \\
\hline
\end{tabular}

Populasi dari penelitian ini yaitu seluruh perawat tetap yang bekerja di RS XYZ dan memberikan pelayanan pada pasien terduga atau terkonfirmasi COVID-19 RS XYZ di Tangerang pada tahun 2021. Sampel pada penelitian ini adalah perawat yang bekerja full time atau perawat tetap RS XYZ yang memberikan pelayanan atau bersinggungan dengan pasien yang diduga terinfeksi virus
COVID-19. Pengambilan sampel dilakukan di bulan Maret - April 2021 dalam kondisi pandemi COVID-19. Untuk menghitung jumlah sampel yang diperlukan pada populasi yang jumlahnya diketahui, maka pada penelitian ini digunakan metode perhitungan Krejcie \& Morgan (1970). Sampel penelitian yang memenuhi syarat adalah sejumlah 80 responden. Metode pengambilan 
sampel penelitian ini adalah simple random sampling. Responden yang telah memenuhi kriteria awal akan dikirim tautan kuesioner yang dapat diisi secara online. Metode analisis data penelitian ini menggunakan analisis multivariate karena kompleksitas dari model penelitian dan adanya penggunaan variabel laten atau konstruk (Sekaran \& Bougie, 2016). Terdapat sepuluh variabel dengan sembilan jalur serta terdapat satu variabel mediasi. Karenanya, dibutuhkan metode yang dapat menguji pengaruh antar variabel secara simultan menuju ke variabel terikatnya. Peneliti menggunakan metode analisis PLS-SEM karena model struktural yang kompleks dan mencakup banyak indikator dan hubungan model dan bersifat pengembangan teori dalam penelitian exploratory, serta mampu mengetahui kemampuan explanation dan predictive untuk pengembangan lebih lanjut (Hair et al., 2019). Terdapat dua jenis model yang dihasilkan oleh analisa PLS-SEM yaitu outer model dan inner model. Outer model atau model pengukuran menguji hubungan antara indikator dan variabel konstruk, meliputi dua bagian yaitu uji reliabilitas dan uji validitas. Tahap pengujian reliabilitas meliputi indicator reliability (outer loading), dan construct reliability (Cronbach's alpha dan composite reliability). Tahap pengujian validitas meliputi construct validity (average variance extracted) dan discriminant validity (heterotraitmonotrait ratio). Bila empat hal tersebut sudah memenuhi syarat reliabilitas dan validitas maka dapat melanjutkan ke tahap berikutnya. Selanjutnya adalah inner model atau model struktural yang memberikan hubungan antar konstruk dalam model penelitian, menilai kualitas model dan menguji signifikansi pengaruh dan analisis koefisien. Langkah pertama model ini adalah pengujian multikolinearitas yang berdasar pada nilai variance inflation factor (VIF). Langkah kedua adalah penentuan kemampuan explanatory dan predictive model penelitian dengan menggunakan koefisien determinan atau $R^{2}$ yang berkisar antara 0 dan 1 dimana hasil lebih tinggi menunjukkan akurasi dan prediksi yang lebih tinggi. Hasil tersebut dapat terbagi menjadi tiga tingkat yaitu $0,75,0,5$ dan 0,25 atau disebut substansial, moderat, dan lemah. Ketiga adalah penilaian kemampuan prediksi suatu model bila ada perubahan data dengan $\mathrm{Q}^{2}$ atau predictive relevance. Nilai $Q^{2}$ predict yang lebih dari nol menunjukkan model memiliki prediksi yang baik bila terdapat perubahan data dalam analisis. Sebaliknya, nilai $Q^{2}$ predict yang kurang dari nol menunjukkan model tidak memiliki prediksi yang relevan. Tahapan selanjutnya merupakan tahap pengujian hipotesis yang didapatkan dari menu bootstrapping atau resampling pada SmartPLS. Hal ini dilakukan dengan melihat dua penilaian . Penilaian pertama adalah signifikansi hubungan antara variabel dengan menggunakan nilai Ttabel dengan T-statistik. Apabila T-statistik memiliki nilai yang lebih tinggi dari T-tabel, maka pengaruh variabel dinyatakan signifikan. Sebaliknya, jika nilai T-statistik memiliki nilai lebih rendah dari T-tabel, maka pengaruh variabel dinyatakan tidak signifikan. Penelitian ini menggunakan tingkat signifikansi dimana $\alpha=$ 0,05 , dan degree of freedom digolongkan sebagai infinity, maka didapatkan nilai T-tabel untuk pengujian satu sisi (one tailed test) sebesar 1,645 (Beyer, 2017). Penilaian kedua adalah analisis jalur untuk melihat kekuatan jalur melalui variabel mediasi, serta melihat kemampuan mediasi dari variabel mediasi penelitian dengan cara melihat specific indirect effect. Tahap terakhir analisis SmartPLS adalah dengan menggunakan importance performance map analysis (IPMA) untuk melihat kombinasi antara analisis deskriptif dengan analisis inferensial. Kombinasi dari dua analisis tersebut digambarkan dalam pemetaan dua aksis yang menunjukkan posisi variabel dan indikator berdasarkan mean (analisis deskriptif) dan total effect (analisis inferensial) di gambar tersebut (Sarstedt, 2017). IPMA dapat memberikan gambaran praktikal mengenai apa saja yang perlu ditingkatkan oleh manajemen.

\section{HASIL}

Dari sebanyak 80 responden yang telah memenuhi kriteria penelitian dapat ditemukan gambaran profil responden sebagai berikut:

Tabel 2. Profil Demografi Responden

\begin{tabular}{cccc}
\hline Deskripsi & Kategori & Jumlah & Persentase (\%) \\
\hline Status Kepegawaian & Pegawai Tetap & 80 & 100
\end{tabular}




\begin{tabular}{|c|c|c|c|}
\hline & Pegawai Tidak Tetap & 0 & 0 \\
\hline & Total & 80 & 100 \\
\hline \multirow[t]{3}{*}{ Jenis Kelamin } & Perempuan & 64 & 80 \\
\hline & Laki-laki & 16 & 20 \\
\hline & Total & 80 & 100 \\
\hline \multirow[t]{6}{*}{ Usia } & $<20$ Tahun & 0 & 0 \\
\hline & 21 - 30 Tahun & 64 & 80 \\
\hline & $31-40$ Tahun & 15 & 18.75 \\
\hline & $41-50$ Tahun & 1 & 1.25 \\
\hline & $51-60$ Tahun & 0 & 0 \\
\hline & Total & 80 & 100 \\
\hline \multirow[t]{5}{*}{ Pendidikan Terakhir } & SMA & 0 & 0 \\
\hline & Diploma & 12 & 15 \\
\hline & S1 & 25 & 31.25 \\
\hline & Profesi Ners & 43 & 53,75 \\
\hline & Total & 80 & 100 \\
\hline \multirow[t]{12}{*}{ Lama Bekerja Sebagai Perawat } & $<1$ Tahun & 11 & 13,75 \\
\hline & 1-2 Tahun & 17 & 21,25 \\
\hline & $2-3$ Tahun & 22 & 27,50 \\
\hline & 3-4 Tahun & 8 & 10 \\
\hline & 4-5 Tahun & 4 & 5 \\
\hline & 5-6 Tahun & 5 & 6,25 \\
\hline & 6-7 Tahun & 4 & 5 \\
\hline & $7-8$ Tahun & 2 & 2,50 \\
\hline & $8-9$ Tahun & 2 & 2,50 \\
\hline & $9-10$ Tahun & 2 & 2,50 \\
\hline & > 10 Tahun & 3 & 3,75 \\
\hline & Total & 80 & 100 \\
\hline \multirow[t]{4}{*}{ Departemen } & ICU & 19 & 23,75 \\
\hline & Rawat Inap (RI) & 58 & 72,50 \\
\hline & ICU dan RI & 3 & 3,75 \\
\hline & Total & 80 & 100 \\
\hline \multirow[t]{4}{*}{ Durasi Kerja (per minggu) } & $35-42$ jam & 45 & 56,25 \\
\hline & $43-50$ jam & 35 & 43,75 \\
\hline & > 50 jam & 0 & 0 \\
\hline & Total & 80 & 100 \\
\hline \multirow[t]{3}{*}{ Pernah Bekerja Di Tempat Lain } & Pernah & 49 & 61,25 \\
\hline & Tidak & 31 & 38,75 \\
\hline & Total & 80 & 100 \\
\hline \multirow[t]{3}{*}{ Pernah Terkonfirmasi COVID-19 } & Pernah & 13 & 16,25 \\
\hline & Tidak & 67 & 83,75 \\
\hline & Total & 80 & 100 \\
\hline
\end{tabular}

Sumber: Hasil Pengolahan Data Penelitian (2021)

Tabel diatas menunjukkan bahwa responden terbagi bervariasi antara usia 20 hingga 50 tahun dan dari data tersebut dapat diasumsikan bahwa responden sudah mempunyai kematangan secara emosional. Latar belakang pendidikan responden mayoritas mempunyai pendidikan profesi ners dan dilanjutkan dengan S1 dan Diploma. Dengan latar belakang tersebut, responden dianggap berkompeten dan mampu memahami pertanyaan yang ada pada kuesioner dengan baik. Untuk lama bekerja sebagai perawat, ditemukan hasil yang beragam, namun hasil terbanyak adalah dua sampai tiga tahun. Mayoritas responden bekerja di bangsal rawat inap reguler dan sebagian bekerja di ruang rawat inap intensif. Informasi tersebut dapat memberikan gambaran tentang profil responden yang terlibat menangani COVID-19 berdasarkan derajat keparahannya. Dari segi durasi kerja, responden terbagi menjadi bekerja dengan durasi 35-42 jam per minggu dan 43-50 jam per minggunya. Hal ini dapat mempengaruhi tingkat 
stres yang dialami para responden dari sisi beban kerja dan durasi kerja yang dialami. Manajemen rumah sakit perlu memperhatikan beban kerja yang dialami oleh tiap perawat agar tercipta kesamarataan, serta melihat pola ketenagaan para perawat. Sebagian besar responden pernah bekerja di tempat lain sebelumnya dan sebagian belum pernah bekerja di tempat lain. Hal ini mungkin mempengaruhi perbandingan kualitas kerja yang dialami oleh responden di tempat kerja yang lama. Terakhir, mayoritas dari responden tidak pernah terkonfirmasi COVID-19 dan beberapa diantaranya pernah terkonfirmasi terinfeksi COVID-19. Melihat dari hal tersebut, manajemen RS perlu memperhatikan ketersediaan alat pelindung diri (APD) dan keamanan kondisi lingkungan kerja agar melindungi perawat dalam melakukan pekerjaan mereka.

Tabel 3. Discriminant Validity

\begin{tabular}{|c|c|c|c|c|c|c|c|c|c|c|}
\hline Variabel & 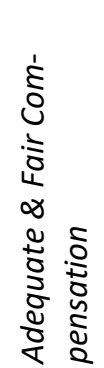 & 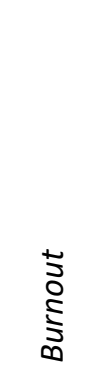 & 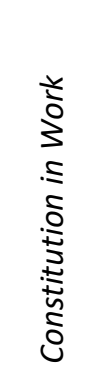 & 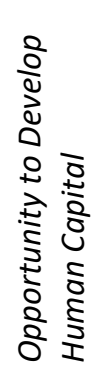 & 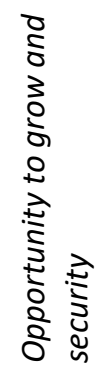 & 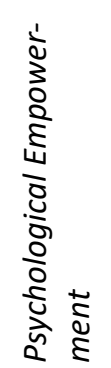 & 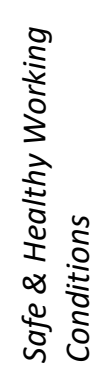 & 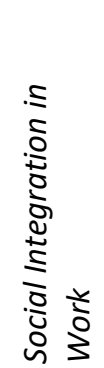 & 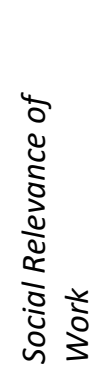 & 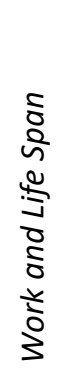 \\
\hline \multicolumn{11}{|l|}{ Adequate \& Fair Compensation } \\
\hline Burnout & 0,590 & & & & & & & & & \\
\hline Constitution in Work & 0,751 & 0,493 & & & & & & & & \\
\hline $\begin{array}{l}\text { Opportunity to Develop Human } \\
\text { Capital }\end{array}$ & 0,794 & 0,480 & 0,819 & & & & & & & \\
\hline $\begin{array}{l}\text { Opportunity to grow and secu- } \\
\text { rity }\end{array}$ & 0,804 & 0,665 & 0,695 & 0,743 & & & & & & \\
\hline Psychological empowerment & 0,726 & 0,768 & 0,691 & 0,519 & 0,699 & & & & & \\
\hline $\begin{array}{l}\text { Safe \& Healthy Working Condi- } \\
\text { tions }\end{array}$ & 0,697 & 0,532 & 0,762 & 0,787 & 0,656 & 0,658 & & & & \\
\hline Social Integration in Work & 0,755 & 0,635 & 0,813 & 0,800 & 0,775 & 0,734 & 0,822 & & & \\
\hline Social Relevance of Work & 0,808 & 0,610 & 0,692 & 0,780 & 0,702 & 0,620 & 0,683 & 0,728 & & \\
\hline Work and Life Span & 0,550 & 0,458 & 0,427 & 0,501 & 0,414 & 0,396 & 0,532 & 0,476 & 0,600 & \\
\hline
\end{tabular}

Sumber: Hasil Pengolahan Data Penelitian (2021)

Pada tabel diatas dapat dilihat hasil uji discriminant validity yang dilakukan dimana didapatkan nilai rasio heterotrait-monotrait (HT/MT) dari setiap variabel berada di bawah 0,9. Dapat disimpulkan bahwa semua indikator pada model penelitian ini telah terdiskriminasi dengan baik dan dapat mengukur konstruknya masing-masing. Setiap indikator dapat dengan tepat dan spesifik mengukur konstruknya. Dengan mengacu pada empat parameter pengujian reliabilitas dan validitas dari outer model diatas yaitu indicator reliability (outer loading), construct reliability (Cronbach's alpha dan composite reliability), construct validity (average variance extracted), dan discriminant validity (heterotrait-monotrait ratio), model penelitian ini memiliki indikator yang reliabel dan valid untuk dapat mengukur konstruknya masing-masing secara spesifik dan dapat melanjutkan ke tahap analisis berikutnya yaitu uji inner model (model struktural). Tahapan berikutnya merupakan uji signifikansi pada sembilan jalur atau path untuk melihat apakah signifikasi pengaruh antar variabel dalam model agar dapat digeneralisir pada tingkat populasi. Untuk itu, dilakukan bootstrapping dengan re-sampling pada SmartPLS.

Tabel 4. Hasil Uji Hipotesis

\begin{tabular}{|c|c|c|c|c|c|}
\hline No & Jalur & $\begin{array}{c}\text { Standardized } \\
\text { Coefficient }\end{array}$ & T-statistik & Signifikansi & Hasil \\
\hline
\end{tabular}




\begin{tabular}{|c|c|c|c|c|c|}
\hline $\mathrm{H} 1$ & $\begin{array}{l}\text { Adequate and Fair Compensation -> Psycho- } \\
\text { logical Empowerment }\end{array}$ & 0,361 & 2,616 & Signifikan & $\begin{array}{l}\text { Hipotesis } \\
\text { didukung }\end{array}$ \\
\hline $\mathrm{H} 2$ & $\begin{array}{l}\text { Constitution in Work -> Psychological Em- } \\
\text { powerment }\end{array}$ & 0,309 & 2,559 & Signifikan & $\begin{array}{l}\text { Hipotesis } \\
\text { didukung }\end{array}$ \\
\hline H3 & $\begin{array}{l}\text { Opportunity to Grow and Security -> Psycho- } \\
\text { logical Empowerment }\end{array}$ & 0,239 & 2,051 & Signifikan & $\begin{array}{l}\text { Hipotesis } \\
\text { didukung }\end{array}$ \\
\hline $\mathrm{H} 4$ & $\begin{array}{l}\text { Opportunity to Develop Human Capital -> } \\
\text { Psychological Empowerment }\end{array}$ & 0,627 & 4,657 & Signifikan & $\begin{array}{l}\text { Hipotesis } \\
\text { didukung }\end{array}$ \\
\hline H5 & $\begin{array}{l}\text { Social Integration in Work -> Psychological } \\
\text { Empowerment }\end{array}$ & 0,270 & 1,926 & Signifikan & $\begin{array}{l}\text { Hipotesis } \\
\text { didukung }\end{array}$ \\
\hline H6 & $\begin{array}{l}\text { Social Relevance in Work -> Psychological } \\
\text { Empowerment }\end{array}$ & 0,102 & 0,792 & $\begin{array}{l}\text { Tidak Signif- } \\
\text { ikan }\end{array}$ & $\begin{array}{c}\text { Hipotesis } \\
\text { tidak } \\
\text { didukung }\end{array}$ \\
\hline $\mathrm{H7}$ & $\begin{array}{l}\text { Safe and Healthy Working Conditions -> } \\
\text { Psychological Empowerment }\end{array}$ & 0,236 & 1,974 & Signifikan & $\begin{array}{l}\text { Hipotesis } \\
\text { didukung }\end{array}$ \\
\hline $\mathrm{H} 8$ & $\begin{array}{l}\text { Work and Life Span -> Psychological Em- } \\
\text { powerment }\end{array}$ & 0,030 & 0,352 & $\begin{array}{l}\text { Tidak Signif- } \\
\text { ikan }\end{array}$ & $\begin{array}{c}\text { Hipotesis } \\
\text { tidak } \\
\text { didukung }\end{array}$ \\
\hline H9 & Psychological Empowerment -> Burnout & $-0,756$ & 12,679 & Signifikan & $\begin{array}{l}\text { Hipotesis } \\
\text { didukung }\end{array}$ \\
\hline
\end{tabular}

Sumber: Hasil Pengolahan Data Penelitian (2021)

Tabel hasil uji hipotesis diatas menunjukkan bahwa dari sembilan hipotesis dalam model penelitian yang diuji, ditemukan tujuh hipotesis yang terbukti signifikan dan memiliki arah yang sesuai dengan arah pada hipotesis yang diajukan, sehingga dapat dikatakan ketujuh hipotesis tersebut didukung. Dua hipotesis memiliki arah yang sesuai, namun tidak signifikan sehingga hipotesis tidak didukung. Uraian untuk masing-masing hipotesis dapat digambarkan dengan model dibawah ini:

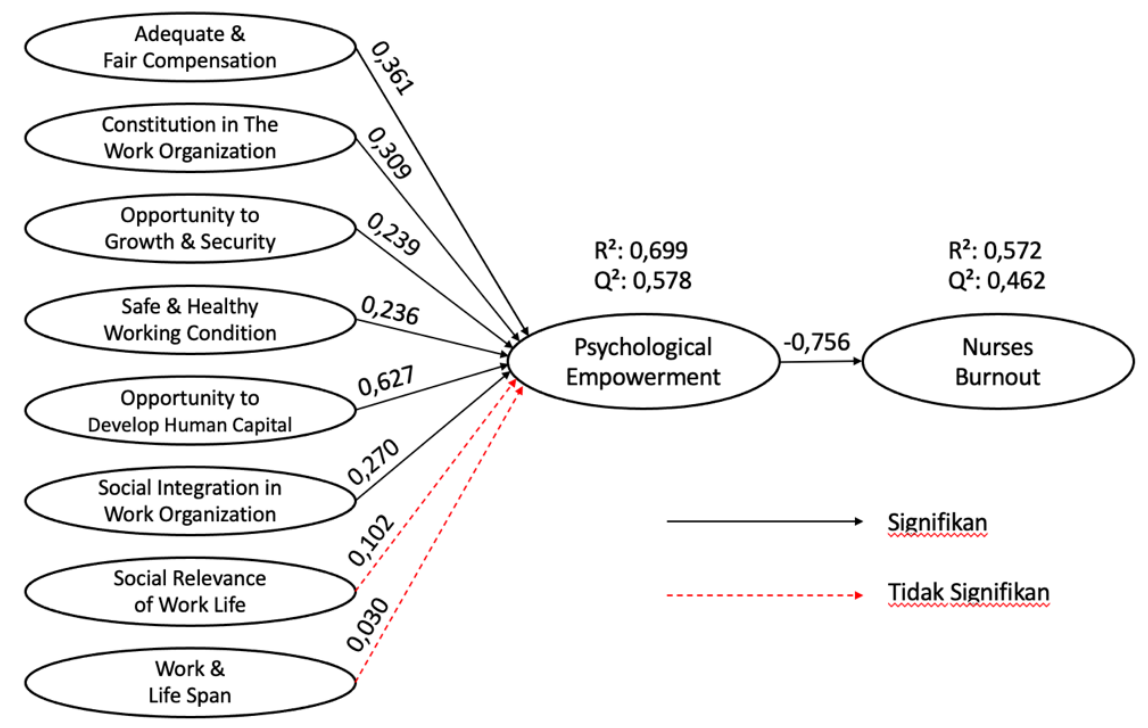

Gambar 2. Gambar Model Hasil (Empirical Model)

Sumber: Hasil Pengolahan Data Penelitian (2021)

Hasil analisis dengan PLS-SEM pada model diatas dapat digunakan sebagai model empiris (empirical model). Berdasarkan model tersebut diketahui bahwa dari sembilan jalur yang diuji, tujuh diantaranya terbukti secara signifikan dan mempunyai pengaruh sesuai dengan arah hipotesis sehingga dapat dikatakan hipotesis didukung (supported), sedangkan dua 
diantaranya tidak signifikan sehingga dapat dikatakan hipotesis tidak didukung. Model penelitian yang dilakukan ini dapat diterapkan dan dilakukan pengujian pada populasi yang lebih luas berdasarkan cakupan geografisnya. Analisis model struktural memberikan hasil bahwa model peneliitan ini mempunyai moderate predictive accuracy dan medium predictive relevance pada variabel dependen burnout dan variabel mediasi psychological empowerment. Oleh karena itu, model penelitian ini dapat dikembangkan lebih lanjut dengan jumlah sampel yang lebih besar lagi dan penerapan kriteria responden yang lebih ketat lagi untuk memperoleh hasil yang lebih prediktif.

Enam variabel independen dalam model ini mempunyai pengaruh yang signifikan dan pengaruh yang paling kuat diketahui berasal dari opportunity to develop human capital terhadap psychological empowerment sebesar 0,627. Selanjutnya, hasil analisis specific indirect effect juga menunjukkan bahwa jalur yang memiliki pengaruh paling besar dari variabel independen menuju ke burnout juga berasal dari opportunity to develop human capital. Faktor yang berhubungan dengan otonomi dan kelayakan pemberian tugas serta penilaian kinerja menjadi hal yang sangat penting bagi perawat yang bekerja di rumah sakit, sehingga manajemen rumah sakit perlu untuk lebih memprioritaskan hal tersebut. Kinerja tersebut juga relevan dengan kondisi pandemi COVID-19 dimana beban kerja yang diberikan berbeda dibanding biasanya dan penilaian kinerja yang juga berbeda di rumah sakit. Variabel kedua yang tidak kalah penting adalah adequate and fair compensation sebesar 0,361 . Faktor yang berhubungan dengan gaji dan insentif atau penghargaan menjadi hal terpenting kedua yang diperhatikan oleh perawat di rumah sakit. Temuan-temuan lain dari penelitian ini juga menunjukkan pentingnya variabel-variabel yang diteliti dan menunjukkan hasil signifikan untuk diprioritaskan oleh manajemen rumah sakit untuk meningkatkan kinerja perawat. Variabel mediasi yang digunakan yaitu psychological empowerment terbukti menunjukkan pengaruh yang signifikan dalam mengurangi terjadinya burnout dan mampu memediasi pengaruh variabel independen dan temuan tersebut sejalan dengan penelitian terdahulu terkait dengan kualitas kehidupan kerja dan psychological empowerment terhadap burnout pada perawat
(Permarupan et al., 2020). Para perawat tentunya ingin agar mereka mendapatkan otonomi atau kesempatan untuk membuat keputusan dan mendapatkan beban kerja yang wajar, serta memperoleh kompensasi yang layak atas apa yang sudah mereka lakukan dalam melayani pasien. Bila hal tersebut terpenuhi dengan baik, dapat mencegah terjadinya burnout atau kelelahan perawat yang nantinya menimbulkan dampak negatif bagi pelayanan rumah sakit.

\section{KESIMPULAN}

Penelitian ini menggunakan replikasi dari model penelitian terdahulu dengan komponen dari quality of work life sebagai variabel independen dan psychological empowerment sebagai variabel mediasi, serta burnout sebagai variabel dependen. Didapatkan bahwa dari sembilan hipotesis, tujuh diantaranya terbukti didukung dengan signifikan dan arah pengaruh yang sesuai. Berdasarkan analisis model struktural dapat diketahui bahwa model penelitian ini memiliki moderate predictive accuracy dan medium predictive relevance pada variabel dependen burnout. Oleh sebab itu, model penelitian ini layak digunakan dan dapat dikembangkan lebih lanjut lagi pada penelitian selanjutnya. Penelitian ini menunjukkan bahwa mayoritas responden merupakan usia 21-30 tahun yang mencerminkan usia dimana seseorang baru menyelesaikan pendidikan dan baru bekerja. Didukung oleh data tambahan bahwa responden mayoritas memiliki pengalaman bekerja yang relatif rendah menjadi catatan penting karena paparan terhadap pasien dan pengalaman kerja mungkin saja berpengaruh pada kondisi perawat terutama dalam aspek psikologis. Berdasarkan hasil penelitian, dapat disimpulkan bahwa opportunity to develop human capital sangatlah berpengaruh terhadap pemberdayaan psikologis para perawat. Hal ini berkaitan dengan penyediaan lingkungan kerja yang memfasilitasi perawat untuk mendapat kesempatan dan memperoleh otonomi yang layak. Oleh sebab itu, manajemen rumah sakit perlu memperhatikan hal tersebut dengan lebih maksimal lagi. Rumah sakit perlu untuk menyediakan peluang yang adil bagi tiap perawat di rumah sakit, serta memberikan mereka wewenang untuk mengakses informasi terkait dengan tugas mereka, dan kesempatan untuk membuat keputusan yang terkait dengan pekerjaan mereka 
sehari-hari. Pada aspek pemberdayaan psikologis perawat, ditemukan bahwa rasa importance memiliki peranan yang sangat penting, terutama perasaan memiliki pengaruh atas apa yang terjadi di rumah sakit tempat perawat tersebut bekerja. Seorang perawat yang tidak mengetahui hal-hal yang terkait dengan kondisi terkini yang terjadi di rumah sakit atau pasiennya akan merasa kurang diberdayakan secara psikologis. Manajemen rumah sakit perlu untuk lebih peka terhadap hal tersebut dan mengoptimalkan sistem informasi bagi para perawat, agar lebih update terhadap hal yang terjadi di tempatnya bekerja, serta dapat memberikan pendapat dan pengaruh terhadap hal-hal yang terjadi di tempatnya bekerja. Pada aspek kelelahan pada perawat, ditemukan bahwa penyediaan lingkungan kerja yang memfasilitasi perawat untuk mendapatkan kesempatan dan otonomi memegang peranan yang tinggi untuk mengurangi tingkat kelelahan perawat di rumah sakit. Manajemen rumah sakit dapat memperhatikan otonomi yang layak bagi para perawat. Rumah sakit juga perlu untuk mengevaluasi berkala sistem penilaian yang ada di rumah sakit untuk memastikannya berjalan dengan baik dan benar. Manajemen juga perlu memperhatikan kewajaran tugas yang diberikan pada perawat, ketika perawat merasa bahwa tugas yang ada dalam tingkat yang wajar, maka kelelahan akan berkurang dan mereka akan mampu untuk bekerja dengan lebih maksimal. Penelitian terkait topik pengembangan sumber daya manusia (SDM) di rumah sakit di masa pandemi COVID-19 tergolong jarang dilakukan. Hal ini menjadi peluang untuk lebih memperdalam lagi aspek yang berkaitan dengan hal tersebut untuk dapat dikembangkan menjadi peluang dalam memberikan pelayanan rumah sakit yang lebih baik kepada pasien dan masyarakat. Sehubungan dengan hal itu, terdapat beberapa keterbatasan yang diperoleh dari penelitian ini. Pertama, penelitian ini memiliki keterbatasan dalam hal metode penarikan sampel yang dilakukan yaitu melalui kuesioner secara online yang dilakukan karena masih dalam kondisi pandemi COVID-19. Kuesioner yang dilakukan secara online memiliki kelemahan yaitu kondisi responden tidak dapat diketahui dengan pasti. Faktor emosi ataupun mood responden saat akan mengisi kuesioner dapat mempengaruhi hasil pengisian kuesioner. Saran untuk penelitian selanjutnya adalah dapat dipertimbangkan untuk melakukan pengambilan data ataupun distribusi kuesioner pada responden secara tatap muka, dengan tetap menerapkan protokol kesehatan seperti physical distancing, penggunaan masker, dan lainnya. Kedua, keterbatasan penelitian ini berkaitan dengan besar sampel yang berhubungan dengan kemampuan prediksi model penelitian. Oleh sebab itu, penelitian selanjutnya dapat menambah jumlah sampel dan juga disertai dengan cakupan geografis yang lebih luas lagi. Misalnya tidak hanya terbatas terhadap satu rumah sakit melainkan terhadap kumpulan rumah sakit lain yang ada di kota-kota besar lainnya sehingga dapat lebih mewakili populasi dengan lebih baik. Peneliti selanjutnya juga dapat menambahkan variabel atau pemediasi yang digunakan agar dapat meningkatkan kemampuan ketepatan akurasi dalam memprediksi variabel dependen yang digunakan dalam model penelitian. Ketiga, dapat disarankan bagi peneliti selanjutnya untuk membuat penelitian yang lebih spesifik berdasarkan dengan tipe departemen tempat responden bekerja. Hal tersebut diperlukan karena beban kerja dan scope of work tiap departemen berbeda-beda satu dengan yang lainnya, yang mampu menghasilkan stresor tersendiri bagi para perawat yang bekerja. Dengan membuat kategori tersebut diharapkan data dari responden dapat dianalisis lebih mendalam dan menghasilkan temuan yang lebih spesifik, dan mampu memberikan implikasi yang lebih baik bagi manajemen rumah sakit agar meningkatkan pelayanan kesehatan yang lebih baik bagi pasien.

\section{DAFTAR PUSTAKA}

[1] Catton, H. (2020). Global challenges in health and health care for nurses and midwives everywhere. International Nursing Review, 67(1), 4-6, https://doi.org/10.1111/inr.12578

[2] Pan, Y., Guan, H., Zhou, S., Wang, Y., Li, Q., Zhu, T., ... Xia, L. (2020). Initial CT findings and temporal changes in patients with the novel coronavirus pneumonia (2019-nCoV): a study of 63 patients in Wuhan, China. European Radiology, 30(6), 3306-3309. https://doi.org/10.1007/s00330-02006731-x

[3] Krejcie, R. V., \& Morgan, D. W. (1970). Determining Sample Size for Research Activities. 
Educational and Psychological Measurement, 30(3), 607-610. https://doi.org/10.1177/00131644700300 $\underline{0308}$

[4] Liu, Z., Han, B., Jiang, R., Huang, Y., Ma, C., Wen, J., ... Ma, Y. (2020). Mental Health Status of Doctors and Nurses During COVID-19 Epidemic in China. SSRN Electronic Journal. https://doi.org/10.2139/ssrn.3551329

[5] Kang, L., Li, Y., Hu, S., Chen, M., Yang, C., Yang, B. X., ... Liu, Z. (2020). The mental health of medical workers in Wuhan, China dealing with the 2019 novel coronavirus. The Lancet Psychiatry, $7(3)$. https://doi.org/10.1016/s22150366(20)30047-x

[6] Chen, Q., Liang, M., Li, Y., Guo, J., Fei, D., Wang, L., ... Zhang, Z. (2020). Mental health care for medical staff in China during the COVID-19 outbreak. The Lancet Psychiatry, 7(4). $\quad$ https://doi.org/10.1016/s22150366(20)30078-x

[7] Khamisa, N., Peltzer, K., \& Oldenburg, B. (2013). Burnout in Relation to Specific Contributing Factors and Health Outcomes among Nurses: A Systematic Review. International Journal of Environmental Research and Public Health, 10(6), 2214-2240. https://doi.org/10.3390/ijerph10062214

[8] Schaufeli, W. (2006). The Balance of Give and Take: Toward a Social Exchange Model of Burnout. Revue internationale de psychologie sociale, 1(1), 75-119.

[9] Demerouti, E., Bakker, A. B., Nachreiner, F., \& Schaufeli, W. B. (2000). A model of burnout and life satisfaction amongst nurses. Journal of Advanced Nursing, 32(2), 454-464. https://doi.org/10.1046/j.13652648.2000.01496.x

[10] Permarupan, P. Y., Mamun, A. A., Samy, N. K., Saufi, R. A., \& Hayat, N. (2019). Effect of Psychological Empowerment on Nurses Burnout. The Open Nursing Journal, 13(1), 201-210.

https://doi.org/10.2174/1874434601913 $\underline{010201}$

[11] Walton, R. E. (1975). The diffusion of new work structures: Explaining why success didn't take. Organizational Dynamics, 3(3), 3-22. https://doi.org/10.1016/00902616(75)90027-3
[12] Permarupan, P. Y., Al Mamun, A., Samy, N. K., Saufi, R. A., \& Hayat, N. (2020). Predicting Nurses Burnout through Quality of Work Life and Psychological Empowerment: A Study Towards Sustainable Healthcare Services in Malaysia. Sustainability, 12(1), 388. https://doi.org/10.3390/su12010388

[13] Spreitzer, G. M. (1995). Psychological, Empowerment In The Workplace: Dimensions, Measurement and Validation. Academy of Management Journal, 38(5). https://doi.org/10.2307/256865

[14] Maslach, C., \& Jackson, S. E. (1981). The measurement of experienced burnout. Journal of Organizational Behavior, 2(2), 99-113.

https://doi.org/10.1002/job.4030020205

[15] Sekaran, U., \& Bougie, R. J. (2016). Research Methods For Business: A Skill Building Approach Seventh Edition. John Wiley \& Sons.

[16] Hair, J. F., Howard, M. C., \& Nitzl, C. (2020). Assessing measurement model quality in PLS-SEM using confirmatory composite analysis. Journal of Business Research, 109, 101-110. https://doi.org/10.1016/i.jbusres.2019.11 .069

[17] Hair, J. F., Risher, J. J., Sarstedt, M., \& Ringle, C. M. (2019). When to use and how to report the results of PLS-SEM. European Business Review, 31(1), 2-24. https://doi.org/10.1108/ebr-11-2018$\underline{0203}$

[18] Sarstedt, M., Ringle, C. M., \&amp; Hair, J. F. (2017). Partial Least Squares Structural Equation Modeling. Handbook of Market Research, 1-40. https://doi.org/10.1007/978-3-31905542-8 15-1

[19] Salimi, S., \&amp; Saeidian, N. (2015). Relationship between quality of work life and psychological empowerment by employees' productivity (structural equations modeling). International Journal of Educational and Psychological Researches, 1(1), $10 . \quad$ https://doi.org/10.4103/23952296.147451

[20] Beyer, W. H. (2017). Handbook of tables for probability and statistics. CRC Press. 